\title{
3. Student muckrakers: Applying lessons from non-profit investigative reporting in the US
}

\section{ABBSIRACI}

Drawing on the growth of non-profit investigative reporting centres in the United States, many of which are located in universities, this article proposes the creation of an Australia-New Zealand-Pacific network of university journalism students who collaborate to produce multi-media stories for a website. Tentatively called 'UniMuckraker', the project envisages that teaching with the 'live ammunition' of real journalism would provide an authentic, contextual and team-oriented approach to higher education learning experiences as well as producing quality journalistic content. In conceptualising the model, the article first examines contemporary trends in American investigative reporting with a focus on the increasing number and influence of non-profit centres that have been created following mass layoffs of journalists and closures in the established press. It finds a new willingness by mainstream media to collaborate with highly-specialised non-profit 'factories' that produce investigative stories but notes that the editor/publisher distinction is blurred further in the non-commercial model and that questions have been raised about the motives of the philanthropic funders of non-commercial investigative reporting.

Keywords: foundations, investigative journalism, journalism education, nonprofit journalism, philanthropy

\section{BILL BIRNBAUER}

\section{Monash University}

7 HE ABSENCE of corporate interference, government control, daily deadline pressures or the need to attract advertising places universi-

ties in a strong position to produce quality investigative journalism. This is enhanced by many journalism schools having academic staff with significant experience in the production of journalism. To date, schools in 
Australia-New Zealand and the Pacific region have operated in silos despite the availability of online technologies (websites, Twitter, Facebook, YouTube) that could facilitate collaborations between the schools and students.

This article proposes that universities in those regions form a network in which students studying investigative or in-depth reporting complete assignments on similarly-themed issues. After assessment, the best work would be augmented by editing, videos, and graphics and posted on a website tentatively called UniMuckraker, providing a national or regional perspective of a significant issue.

Teaching with the 'live ammunition' of real journalism would provide an authentic, contextual and team-oriented approach to higher education learning while offering a broader audience a new outlet for quality journalism with concurrent additional opportunities for publication in mainstream media.

The UniMuckraker project draws on models in the United States where a number of producers of investigative journalism have used tertiary students either as interns, research assistants, reporters, assistant editors or video producers. A 'live' example of the intended structure for UniMuckraker, albeit with senior journalists, can be found in the International Consortium of Investigative Journalists, a project of the investigative reporting non-profit organisation, the Centre for Public Integrity. The consortium's membership consists of approximately 100 senior investigative reporters in almost 50 countries.

At the heart of the consortium's concept are investigative reporters in many parts of the world working collaboratively on stories that transcend borders, for example, environmental degradation, the global arms or drug trades and human exploitation. Typically, an investigative project may have a dozen senior journalists in as many countries reporting to a project director who heads a team of copy editors, fact checkers, web producers and graphic artists.

The author first became aware of a model of journalism that was financed by philanthropic foundations when he was invited in February 1998 to join the then newly formed International Consortium of Investigative Journalists, 'an unprecedented new venture to assemble the world's premier journalists in order to produce international investigative reports' (C. Lewis and M. Beelman, personal communication, 17 February 1998). Since joining the consortium, the author has completed two major investigative projects ${ }^{1}$, attended several conferences of consortium members and observed the growth of non-profit centres in the United States. 
While the consortium's structure informs UniMuckraker's vision of increasing the depth of investigative stories by providing a national or regional perspective of issues, another US model, News21, which brings together students at a dozen US universities to partner on investigative stories over 10 weeks of the summer break, contains the nuts and bolts of how the project might be organised (see panel). Five of the deans involved in News21 have drafted a 'manifesto' that calls on J-schools to renew their mission in much the same way as have some schools of business, medicine and law. The 'deans' manifesto' (Manifesto, n.d.) argues that, rather than be thought of as trade schools, journalism schools ought to move into the professional-school realm. 'There is no reason why significant advances in the means and methods of delivering news to the public ought not to emerge from professional schools of journalism, as much as from news organisations themselves' (ibid).

This article is based on interviews in November 2010, with the senior editorial managers and reporters at the four biggest non-profit centres in the US: the Centre for Public Integrity, the Centre for Investigative Reporting, ProPublica and the Investigative Reporting Workshop.

Newspaper closures and the axing of thousands of reporting jobs in the United States media have raised questions about the future of journalism and in particular about how quality investigative reporting might be financed in the face of dwindling staff and financial resources. Despite the welldocumented layoffs and hardships in the established media, this article finds that there has been a shift in investigative reporting practice in the United States since 2006 that has reinvigorated a 'muckraking' culture. Concern about the ability of the media to scrutinise government agencies and powerful institutions has led to the rapid growth since 2006 of philanthropically-funded non-profit investigative reporting centres, some of which are located in universities, as well as the creation of innovative models, such as News21, that use students to produce quality reporting.

This article does not attempt to analyse the output of these models. Rather, it notes the contemporary trends in investigative reporting in the United States and the emergence of specialist, 'industrial-type' not-for-profit centres that may be the most organised attempts ever to transform the ideal of the Press's Fourth Estate watchdog role into reality. Academic literature on the emergence and impact of foundation-funded investigative reporting is scarce (Browne, 2010).

This article draws on the US experience in proposing that university journalism schools in the region collaborate to enrich their students' 
education and create content on issues of importance to the community. Though it is yet to be shown to be the case, the likely absence of a philanthropic culture in Australia, New Zealand and the Pacific that might make large contributions to journalism, combined with questions about whether such donations would attract tax deductibility, raise doubts that an investigative non-profit centre would be viable outside of a university setting.

In Australia, the Centre for Independent Journalism at the University of Technology, Sydney, uses both students, staff and reporters to produce investigative articles and the Public Interest Journalism Foundation at Swinburne University has adopted a US model in which the public contributes financially to pay for reporters to cover stories it suggests. These centres at best can produce locally-based articles that lack a national or international perspective. The UniMuckraker model was conceptualised after observation of and interviews with key players in the field and envisages students across Australia, New Zealand and the Pacific undertaking projects in much the same way as senior reporters collaborating at the International Consortium of Investigative Journalists (see panel), recognising that issues do not stop at state borders.

The article first examines what journalist and academic Charles Lewis argues is the 'dawn of a new investigative journalism ecosystem in the United States, in which the most ambitious reporting projects will increasingly emanate from the public realm, not from private, commercial outlets' (Lewis, 2009, para 4).

\section{New partnerships, a marriage of convenience?}

A transformation has occurred in recent years in the way quality investigative reporting is conducted and distributed in the United States. In November 2010, The Washington Post and its website devoted prominent display to a lengthy investigative story on the 2008 Mumbai terrorist attacks. The story was written and bylined 'Sebastian Rotella, ProPublica' and was published on The Post's and ProPublica's websites (Rotella, 2010; Rotella, 2010a). That a venerable newspaper such as The Washington Post, where reporting by Bob Woodward and Carl Bernstein in the 1970s helped expose the Watergate scandal, would devote such prominence to an expose written by an outside reporting source may appear unusual, but collaborations between established media and non-profit centres now are routine in the US. ProPublica has had 60 mainstream publishing partners since 2008 (R. Tofel, personal communication, November 17, 2010). 
Referencing the release of more than 391,000 classified Pentagon documents on the Iraq war by WikiLeaks in collaboration with The New York Times, The Guardian and Der Spiegel, journalism professor at American University Charles Lewis commented that three years ago The New York Times would not have considered partnering The Guardian. 'They would have said that's a liberal publication, we don't do that; we're The New York Times, we're the Grey Lady' (C. Lewis, personal communication, 8 November 2010). Lewis is founding executive editor of the Investigative Reporting Workshop, a university-based reporting centre and, like other non-profit managers interviewed, he has found the established media knocking on his door for quality content: '... we have to tell them to go away ... we have more than we can deal with. It's slightly amusing on one level and slightly depressing on another. They are desperately seeking content because they have eviscerated their newsrooms' (ibid).

Non-profit centres such as the Centre for Public Integrity, the Centre for Investigative Reporting, ProPublica and others, are regular recipients of journalism's top awards. In 2010 ProPublica in collaboration with The New York Times Magazine won the Pulitzer Prize for investigative reporting, the highest accolade for such work in the United States. ProPublica's reporter Sheri Fink spent two and a half years researching 'Deadly Choices at Memorial', a harrowing narrative of mercy killings at Memorial Hospital in New Orleans in the aftermath of Hurricane Katrina. Fink interviewed 140 people over several months. One estimate of the cost of researching, writing, editing and securing the legal status of the article was \$US400,000 (Jeffery, 2009). It is difficult to envisage a traditional media outlet allocating such resources to a project in the current climate. The bigger non-profit centres are dynamic, creative specialist hubs comprising teams of reporters, editors, data analysts, web producers, graphic designers, subeditors, fact checkers and lawyers involved in the production of high-quality journalism. They represent a significant change of traditional iterations of such work.

\section{Investigative factories are churning it out}

In the 'golden age of public service journalism' in the early 1900s, individual muckraking writers such as Ida Tarbell, Upton Sinclair, and Lincoln Steffens revealed corporate wrongdoing, worker exploitation, social injustice and municipal corruption in their detailed writings (Feldstein, 2006). The period between the First World War until the Vietnam War, with several 
exceptions, constituted the 'Dark Ages' for such reporting, with historians offering various explanations for its demise (ibid., p. 110). The pendulum swung again in the 1960 s, as a 'new muckraking age was born' with a fresh generation of reporters challenging segregation, the Vietnam War, political corruption and corporate malfeasance (ibid., p. 111). Harold Evans' Sunday Times Insight team in Britain inspired at least one editor in Australia to establish an investigative unit (Hills, 2010). Carl Bernstein and Bob Woodward's Watergate break-in revelations provided extra impetus to a 'frenzy of investigative reporting' (Feldstein, 2006) that began to wane at the end of the 1970s (ibid., p. 112). In Australia, the 1980s was a decade when journalism became significantly and consistently more investigative than it had been (Schultz, 1998, pp. 19-22). In the 1990s, however, the media's focus turned to celebrities, entertainment and the 'predictable moral certainty of goodies and baddies' (ibid., p. 14).

Overlaying these cycles was a progressively growing distinction and specialisation in the process of investigative journalism production. This article suggests that the apogee of specialisation in investigative reporting is most apparent in the bigger non-profit centres operating in the United States. New York-based ProPublica, with a budget of more than \$US10 million a year employed 33 full-time reporters in 2010; the Centre for Public Integrity had revenue of \$US8 million in 2008-09 and employed about 40 reporting staff. These investigative reporting 'factories' produced hundreds of investigative stories, winning dozens of top national awards for in-depth journalism. Their stories appeared in the quality press, public radio and television programmes such as PBS's Frontline.

The template for non-profit investigative journalism in the United States was established between 1969 and 1977 when three organisations were created: the Centre for Investigative Reporting, the Fund for Investigative Journalism and Investigative Reporters and Editors (IRE). The centre produced investigative reports, the fund financed them and the IRE was a professional association for investigative reporters. No further centres were established for 12 years until 1989 when Charles (Chuck) Lewis, then producer for the American 60 Minutes programme, resigned and created the Centre for Public Integrity. Since 2006, there has been rapid growth in the US (and globally) in the number of non-commercial news centres: there are now more than 60 in the United States and their number is increasing (Lewis, 2010). A 2007 
study of global support for investigative journalism located 40 centres outside the US - there were three in the 1980s (Kaplan 2007, p. 7). The Investigative News Network, an umbrella group established in 2009 to provide back-office support to US non-profit centres, now has more than 50 members. The growth in the number of reporting centres and the substantial philanthropic support they attract - more than \$US140 million between 2006 and 2009 (Schaffer, 2010, para 61) - is linked to the closure and layoffs over the same period in mainstream media: foundations concerned about accountability and democratic governance have directed funding to the centres and journalists who have lost their jobs have moved to the centres or established their own operations.

The economic forces, industry shifts and technologies behind the devastation of the US press have been discussed elsewhere (Leonard Downie, 2009; Meyer, 2009; Nichols, 2010) and it suffices here to reiterate that daily newspapers in the US cut 13,500 journalists from their books between 2007 and April 2010 (Editors, 2010). American newsrooms lost more than 25 percent of their full-time staff in that period, bringing the total of fulltime journalists in daily newsrooms to 41,500, a level not seen since the mid-1970s. Investigative journalism was not protected: membership of Investigative Reporters and Editors (IRE) fell more than 30 percent, from 5,391 in 2003 to a 10-year low of 3,695 in 2009, and applications for the Pulitzer Prize dropped by up to 40 percent in some investigative categories (Walton, 2010, para 7).

The number of reporters transitioning to non-profit models, however, did not come close to the layoffs in the mainstream press. Mary Walton in American Journalism Review estimated the total number of full-time investigative reporters in the three largest US non-profit centres at between 80 and 100 (Walton, 2010, para 87). Lewis's research, on the other hand, found that 60 US non-profit journalism sites and organisations employed 658 full-time staff (Lewis, 2010), two-thirds of whom had prior journalistic experience. Lewis reported that 63 percent of non-profit centres were created after 2006. The budgets of the 60 groups totalled between \$US80 million and \$US85 million. A study (Schaffer, 2009, para 7) by Jan Schaffer, executive director of J-Lab, found that 180 foundations contributed a total of \$US128 million to 'news and information initiatives' between 2006 and 2009. In February 2010, she revised the figure to 'at least $\$ 142$ million'(Schaffer, 2010, para 61). To put that into perspective, the US Giving Foundation estimates that Americans donated more than \$US307 billion to charitable causes in 2008 despite poor economic conditions. 


\section{Sleeping watchdogs awake!}

The watchdog role, of all the functions of the press in American public life, is the most hallowed but at the same time the least securely institutionalised in the daily mission of today's news (Serrin, 2005, p. 169). Media academics W. Lance Bennett and William Serrin have defined investigative journalism as independent scrutiny of government, business and other public institutions with the aim of documenting, questioning and investigating those activities to provide publics and officials with timely information on issues of public concern. Investigative Reporters and Editors (IRE) has added two ingredients to that definition. The reporting was through one's own work or initiative and concerned important matters that some persons or organisations wished to keep secret. Other common definitions state that investigative reporters 'are pointing out that it (society) is failing by its own standards' (Burgh, 2008, p. 20) and that their work 'calls us, as a society, to decide what is, and what is not, an outrage to our sense of moral order ... In this way investigative journalists are custodians of public conscience" (Ettema \& Glasser, 1998, p. 3). James Aucoin's definition in The evolution of American investigative journalism (2005, p. 91) embraces most of the key elements of other definitions. He recognised five components of investigative reporting: 1) exposure of information, 2) about an important public issue, 3) that someone or some organisation does not want reported, 4) that is revealed through the original, time-consuming 'digging of the reporter', 5) for the purpose of inspiring reform (Aucoin, 2005, p. 91).

A widely-held sentiment among US non-profit editors and journalists is that they were doing investigative projects and stories that traditional media either ignored or regarded as too expensive, time-consuming or legally fraught. Similar sentiments about the inability of mainstream media to fulfil their traditional roles are echoed on the websites of many non-profit centres:

We're launching this service because the owners of newspapers and television news teams have, in too many cases, cut back on investigating government and chipped away at their ability to be a watchdog for the voter and the taxpayer--Texas Watchdog: www.texaswatchdog.org

Investigative reporting and storytelling takes time, resources and talent that many traditional news outlets can no longer afford.-Investigate West: http://invw.org 
Newsrooms across Colorado are half the size they were just a few years ago. Often, there are only enough reporters left to fill the daily demands of a morning newspaper, evening newscast, or to-the-minute web updates. That can leave literally no one to dig deeper into matters of public interest.-Rocky Mountain Investigative News Network: www.inewsnetwork.org

For the reporters, editors, producers, fundraisers and managers at these centres the definitions of investigative journalism cited above hold as true as ever.

\section{Playing the pipers' tunes?}

Philanthropic foundation and individual donations to non-profit news centres are tax deductible in the United States under an 'education' provision in s. 501(c)3 of the US Internal Revenue Code. A clause prohibits exempt organisations from engaging in politically partisan activities like endorsing candidates. Most centres have a 'Donate' button on their websites and regularly appeal to readers for donations. The Washington-based Centre for Public Integrity, like most centres, does not accept money from corporations, unions, advocacy groups, governments, or anonymous donors (Lewis, 2007, p. 10). Between 1989 and 2004, cumulative revenues and expenditures at the centre were about \$US30 million with more than 90 percent coming from foundations such as MacArthur, Knight, Schumann, Ford, Carnegie, Open Society Institute, Annenberg, Newman and others. While the centre provides its findings to the media free of charge, the Centre for Investigative Reporting in Berkeley, California, and other centres, work in paid collaboration with mainstream media organisations, though the income from this amounts to a fraction of total funding. The centres, encouraged by their donating foundations and requirements under US tax laws, are endeavouring to diversify their revenue sources away from foundations. While training, short courses, subscriptions, book sales and exclusive first-use contracts have potential to raise some revenue, a looming issue for non-profits is advertising income. The websites of the bigger centres, because of their collaborations with established media and the wide distribution of their stories in such media, draw millions of unique visitors, possibly making them somewhat attractive to advertisers. ProPublica's general manager Richard Tofel confirmed in an interview (R. Tofel, personal communication, 7 November 2010) that the 
organisation was considering taking advertising, both online and in the form of 'sponsorship' of its daily emails which are sent to 37,000 subscribers. This was later confirmed in a statement (ProPublica 2011) and release of an 'advertising accountability policy' that 'maintains a clear separation between news and advertising content' (ProPublica, 2011a). The Centre for Public Integrity was expected to launch a new website in 2011 that might carry what its senior staff called 'underwriting'. The centre plans to earn half its revenue from income other than foundations in the next five years (B. Buzenberg, personal communication, 11 November 2010).

The introduction of paid advertising could result in pressure for a more rapid turnover of stories in order to maintain and increase the number of unique visitors that advertisers find so alluring. If that occurred, the centres' capacities to produce time-consuming, long-form investigative stories may be eroded or impaired. Online comments (ProPublica, 2011) about ProPublica's decision to carry advertising included: 'I fear for your journalistic independence since accepting advertising generally includes accepting influence', 'Oh boy, not good! good bye pro-publica' (sic), 'It appears that you've accepted a business model under which independence is not possible'. Several contributors, however, were more understanding and less critical.

While donations to investigative centres by everyday 'mums and dads' have been equated to the support given to non-profit 'public goods' such as galleries, museums, orchestras and even poetry (Cohn, 2010) the dependence of the centres on foundations and wealthy individuals has inevitably raised questions of influence and intent. Centre executives insisted that their funders understood they had no say in the direction of the journalism and would only be able to view the stories when they were published.

Jan Schaffer's New Media Makers study (Schaffer, 2009) concluded that foundations donated to journalism that provided a bulwark for democracy, held the powerful to account, and promoted free speech. 'Journalism, after all, has typically been a for-profit business. But that is beginning to change as foundations across the nation realise that shrinking news coverage of local and national issues threatens not only the topics they care about, it also handicaps communities and threatens democracy itself' (ibid.). Her research found that 44 percent of total foundation funding granted to news and information projects since 2005, or more than \$US56 million, went to three investigative centres: ProPublica (\$US30.8 million), the Centre for Public Integrity (\$US18.1 million) and the Centre for Investigative Reporting (\$US7.3 million). 
These groups depend almost entirely on philanthropic support. Manhattan-based ProPublica was formed in 2008 with a three-year commitment of \$US10 million a year from the billionaire former banker Herbert Sandler and his wife Marion. Sandler is the chairman of ProPublica's board. He is a key donor to Democrat-related causes and had sold his bank to a bigger one, pocketing \$US2.4 billion (Nocera, 2008, para 5). He told The New York Times that outrage motivated him to create ProPublica: 'You go a little crazy when power takes advantage of those without power' (ibid.). ProPublica raised \$US1 million in 2009 in extra funding and anticipates raising \$US4 million in 2010 in addition to Sandler's contribution (R. Tofel, personal communication, 17 November 2010).

The Centre for Public Integrity, which started in1989, was the brainchild of Charles Lewis who remained with the centre until 2004. The centre merged with the Huffington Post Investigative Fund in 2010. It is supported by 50 foundations and in 2008-09 had revenue of \$US8.2 million. Membership contributed \$US298,500 and 'other income' a mere \$US11,145.

Traditional journalists believe a Chinese wall separates their work spheres from those that fund their work and look after the business side of media companies. The common understanding is that the publisher deals with the business and revenue while the editor looks after the journalism. Whether this actually is the case is not investigated here but it is apparent from interviews with the heads of non-profit reporting centres that the traditional distinction in roles is blurring, if not absent, at non-profit centres. The top person, often a former senior mainstream editor, is personally involved, the 'go to' person, in seeking funding from foundations and wealthy benefactors. This represents a significant departure from the ideal, even though that separation may have been lost in many newspaper organisations.

Non-profit reporting centres accept general support from foundations and funding for specific projects. Lewis estimated that of the \$US30 million he raised between 1989 and 2004 about one third was in general support. Foundations may be civic-minded bodies but their donations may not be free of strings or baggage (Walton, 2010). Even where editorial decisions were made by editors, the activity of foundations could be seen as 'an exercise in journalistic agenda setting' (ibid.). Writing in a special edition of the Poynter Report, Rick Edmonds likened foundations to emperors and archbishops who commissioned concertos. 'Mozart did the composing but his benefactors could stipulate the size and shape of the thing' (Edmonds, 2001). 
Brant Houston has been in the engine room of investigative reporting in the US for more than three decades. A former print investigative reporter for 17 years, he was executive director of Investigative Reporters and Editors for more than a decade and is now the John S. and James L. Knight chair in investigative and enterprise reporting at the University of Illinois at UrbanaChampaign. In his experience, journalists who moved to senior roles in nonprofit centres quickly discovered they also were publishers: 'They no longer have publishers taking the angry phone calls or worrying about keeping the doors open; they have dual roles, there's no question. The idea of the philanthropist who doles out a few million dollars and hopes for the best and walks away ... doesn't occur that often" (B. Houston, personal communication, 19 November 2010).

Senior non-profit centre editors who deal with a range of foundations are alert to the possibilities of pressure being applied for particular editorial outcomes. 'Some of them would actually think, "we're going to give you this money and we're going to get this result". You have to educate them ...' (D. Noyes, personal communication, 4 November 2010). 'We're not investigators for hire; we won't go into something just because it's on a foundation's agenda' (Kaplan, 2010). 'There are no strings. There's no "you cover this, you cover that".' There is zero conversation with them about stories. They have no knowledge of what we're doing' (R. Rosenthal, personal communication, 3 November 2010).

Just how sustainable the non-profit model of investigative journalism will prove to be is unclear. Foundation support is notoriously fickle, according to Lewis (C. Lewis, personal communication, 8 November 2010). What appears to be the case is that the investigative reporting model is in transition and that US-based foundations and concerned individuals believe that their support fulfils a social need. But at least eight of the 60 nonprofits Lewis examined, and possibly more, had annual operating budgets of less than \$US100,000, 'which means that several experienced journalists are working for little or no pay, volunteering their knowledge and time in the valiant, heroic attempt to create a new institution out of thin air' (Lewis, 2010, para 17). Houston predicted mixed fortunes ahead with some centres having to merge or close. 'In the bigger scheme of things this may just be a bridge to the next sustainable model that may be for-profit in five years' (B. Houston, personal communication, 19 November 2010). 


\section{University students are doing it}

Lewis's research (Lewis, 2010, para 13) established that 14 of the 60 US non-profit centres were linked to universities - a number he expected to rise. Leonard Downie and Michael Schudson's study, 'The Reconstruction of American Journalism', notes that a growing number of universities were publishing the reporting of their student journalists. They quote Eric Newton from the Knight Foundation: 'Many journalism teachers believe you teach journalism with live ammunition that results in real journalism that has real use for their communities' (Leonard Downie, 2009, pp. 59-60).

It is instructive to describe briefly the functions and operations of several university-based centres as part of an examination of how the model might be adapted locally. Noteworthy centres include the Schuster Institute for Investigative Journalism at Brandeis University, the New England Centre for Investigative Reporting at Boston University and the Toni Stabile Centre for Investigative Journalism at Columbia University. Some university-based centres are embedded in a university school while others have memoranda of understanding or contracts with universities (B. Houston, personal communication, 19 November 2010). What the university centres have in common is that they are supported by philanthropic foundations, many use research produced by students and, like other centres, they believe they are filling a gap in the ability of the mainstream media to produce quality, in-depth journalism. The Schuster Institute has a focus on producing investigative stories that deal with social justice and human rights. Director Florence Graves cites clear advantages to being in a university environment that honours freedom of inquiry independent of government and corporate influence and control. 'While we do not teach courses, we hire and mentor students as research assistants, overseeing them as they do investigative reporting legwork. This apprenticeship system plunges students into real-life journalism, teaching the urgency of thorough and accurate research and of critical thinking about public issues' (Graves, n.d.). Students in the journalism programme at the university's American Studies Department interact with the institute in one of three ways: by earning internship credits toward a journalism minor, being paid for partnering with a scholar on a research project or being hired directly.

The New England Centre for Investigative Reporting was created by Boston University's College of Communication which teaches the university's journalism course. One of its key aims is to 'train the next generation 
of investigative reporters including students at Boston University and innercity high schools' (Bergantino, n.d.) The centre offers students non-paying internships for which they can gain course credits as 'reporter-trainees' and the opportunity of being published in one of the centre's media partners, including The Boston Globe. Students have published stories on air safety standards, wrongful convictions, and workplace safety. Several have been picked up by outlets such as The Christian Science Monitor and CNN.

In 2006, the Graduate School of Journalism at Columbia University 'expanded and consolidated its investigative offerings' by establishing the Toni Stabile Centre for Investigative Journalism (Coronel, n.d.). Each year the centre selects 15 students from about 100 who apply to spend 12 months on an investigative project for their Masters degree. Their work has been published in Salon, The Huffington Post, The New York Times and local outlets. These examples indicate that students can be involved in realistic investigative reporting when given the opportunity and under the supervision of senior reporters or academic staff. Australia, New Zealand and the Pacific, however, lack the wealthy foundations that support such centres in the US - a different model is required to snare the talent apparent in university settings.

\section{Discussion}

Soon after the author delivered a paper outlining the UniMuckraker concept at the Media, Investigative Journalism and Technology (MIJT10) conference in Auckland, New Zealand, in December 2010, (Birnbauer, 2010) the proposal was detailed on the Journalism Education Association of Australia's online discussion forum. Reaction on the site and to the author from journalism academics included:

"Glad to see this is really getting going."

“... congratulations ... on this excellent proposal."

'I've always maintained that we have 'time' and 'people' to tackle

larger projects unlike the mainstream media."

"Absolutely-bloody-excellent!!!!! And about time!"

"I think it sounds like a fantastic idea."

Referencing the pragmatic view of American philosophers William James and John Dewey, media critic and commentator Jay Rosen 


\section{The UniMuckraker project}

THE UNIMUCKRAKER project draws inspiration from two models. The International Consortium of Investigative Journalists is a project of the Washington-based investigative non-profit, the Centre for Public Integrity. The consortium's 100 investigative reporter members in almost 50 countries from time to time are invited or asked to work collaboratively in teams on a project which is edited by a central editor working with fact checkers, online producers and copy editors.

News 21 is an innovative partnership, funded by the Knight and Carnegie foundations, which draws together 12 university journalism schools whose best students research and produce multimedia-based investigative stories.

While these models offer the genesis of thinking for the UniMuckraker project, they cannot be transplanted due to the lack of generous philanthropic support that funds the US groups.

Recent experience suggests the time is right to establish the UniMuckraker project though questions pertaining to funding, administration and responsibilities remain unresolved. In December 2010, a paper (Birnbauer, 2010) presented at the Media, Investigative Journalism and Technology (MIJT10) conference in Auckland outlined the concept. Subsequent comments from journalism academics were positive with lecturers from more than a dozen universities expressing support for its further development.

In the same period-the summer break in 2010-2011-six third-year and Masters students at Monash University worked with the author to augment assignments that students had earlier completed about the Victorian Environment Authority's handling of contaminated sites and to post them online in a multimedia format- 'Dangerous Ground: the EPA's toxic legacy' (epadangerousground.com). Following the launch of the site, senior editorial executives at ABC News 24 and its online investigative unit, The Sunday Age and Crikey expressed interest in collaborating on future projects. The Sunday Age published two of the student articles. The response is not surprising given the financial pressures and staff reductions in the mainstream media combined with the unrelenting demand for quality content.

UniMuckraker would be a collaborative and collective effort by participating universities. A representative of each participating university would be a member of UniMuckraker's board. Two approaches are canvassed here: the first envisages the establishment of a university fund to which tax deductible donations could be made. Potential funding partners such as the Journalism Education Association of Australia, the Media Alliance, Australia's Right to Know group, media organisations, foundations and individual philanthropists as well as the participating universities would be asked to support the initiative. If sufficient funding were available, a manager/producer could be employed full-time or part-time to liaise with academic staff and produce the website with the assistance of interested students from participating universities. 


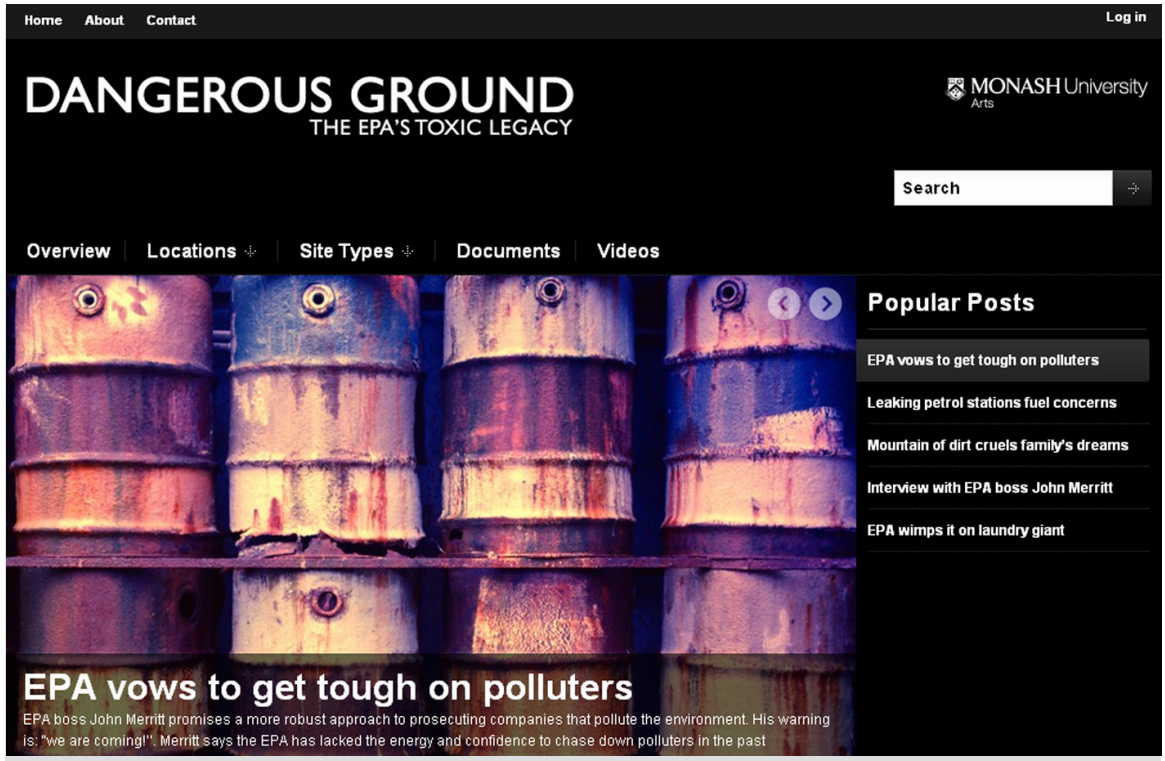

Figure 1: 'Dangerous ground' ... Monash University's investigative journalism website: epadangerousground.com

The alternative model would see lecturers working with students over the mid-year or summer break, with responsibility for the editing rotating between universities. This model is more problematic because many lecturers use nonteaching periods for research or holidays but has the advantage of not relying on outside funding support.

Two principles guiding UniMuckraker should be that it not be 'owned' by a single university and that resulting stories should be offered to a variety of media outlets rather than be tied to one media organisation.

Several journalism lecturers have suggested that students across Australia, New Zealand and Pacific countries might investigate issues that are covered poorly by the daily media. Ideas include homelessness, mental health, the cost of equipment for the disabled, poverty and compulsory land acquisition.

Under the proposed model, students studying investigative reporting or in-depth reporting at the participating universities in Australia, New Zealand and the Pacific would undertake assignments on the same issue or theme. After normal assessments have been completed, selected assignments would be improved or enhanced by editing, videos and graphics either in collaboration with a manager/producer or by lecturers and students.

In time the number of participating students and universities could be expanded with universities in Asia, Europe, the United States and elsewhere joining the network. 
(Rosen, 1999, p. 72) noted that a good idea was a good idea because things could be done with it. The more that could be done, the better the idea.

The UniMuckraker project is a well-received idea that will be refined by discussion and experimentation but is a start that recognises the larger current social and political condition of journalism and holds the potential of energising and enhancing the learning of students.

Staff cutbacks in Australian media organisations have not been as severe as those in the United States-Fairfax and News Limited publications and the $\mathrm{ABC}$ retain investigative reporters - but journalists in both countries are increasingly are complaining they 'are part of the entertainment industry' and 'what seems to worry a growing number of senior journalists is the extent to which entertainment is displacing the more realist concerns of informing citizens' (Davies 1999 pp. 55, 57).

University journalism that is supervised by academic staff has no need to attract advertisers and is free of some of the other constraints - deadlines, the 'objectivity' goal, and a blurring of editor/publisher roles - that inhibit the mainstream media, nor is it required to follow traditional reporting templates. Its defining characteristics should be independence, research depth and quality reporting and multimedia production.

\section{Note}

1. Tobacco Companies Linked to Criminal Organizations in Lucrative Cigarette Smuggling:http://projects.publicintegrity.org/Content.aspx? context=article\&id= 351; The Water Barons: http://projects.publicintegrity.org/water/

\section{References}

Aucoin, J. (2005, p. 91). The evolution of American investigative journalism. Columbia, Mo.: University of Missouri Press.

Bergantino, J. (n.d.). Welcome to the New England Center for Investigative Reporting. Retrieved on 20 December 2010, from http://necir-bu.org/wp/about/

Birnbauer, B. (2010). Building the non-profit road: Investigative lessons and models from other places. Paper delivered at the Media, Investigative Journalism and Technology (MIJT10) conference, AUT University, Auckland, New Zealand.

Browne, H. (2010). Foundation-funded journalism. Journalism Studies, 11(6): 889-903.

Burgh, H. d. (2008, p. 20). Investigative journalism. London: New York, Routledge. Cohn, D. (2010, January 19). The search for a new revenue model in journalism. Retrieved on 20 December 2010, from www.pbs.org/idealab/2010/01/the-searchfor-a-new-revenue-model-in-journalism014.html 
Coronel, S. S. (n.d.). About: Our Mission. Retrieved on 20 December 2010, from http://stabilecenter.org/?page id=2

Davies, C. L. (1999, p. 55, 57). Journalism, corporatism, democracy. Media International Australia 90(February): 53-64.

Editors, A. S. o. N. (2010, November 11). Decline in newsroom jobs slows. Retrieved on 20 December 2010, from http://asne.org/article_view/articleid/763/decline-innewsroom-jobs-slows.aspx

Edmonds, R. (2001). Behind the scenes: How foundations have quietly seized a role in journalism, Commissioning Content. Poynter Report. A. Colon, Poynter Institute.

Ettema, J. S. and T. L. Glasser (1998, p. 3). Custodians of conscience : investigative journalism and public virtue. New York: Columbia University Press.

Feldstein, M. (2006). A muckraking model. Press/Politics 11(2): 105-120.

Graves, F. (n.d.). Welcome from the director. Retrieved on 20 December 2010, from www.brandeis.edu/investigate/about/letter.html

Hills, B. (2010). Breaking news : the golden age of Graham Perkin. Melbourne: Scribe. Jeffery, C. (2009, August 28). Cost of the NYT Magazine NOLA story broken down. retrieved on 20 December 2010, from http://motherjones.com/mojo/2009/08/costnyt-magazine-nola-story-broken-down

Kaplan, D. (2007, p. 7). Global investigative journalism: Strategies for support, Centre for International Media Assistance at the National Endownment for Democracy.

Kaplan, I.-D. (2010, November 1). Interview - David Kaplan. 2010, retrieved on 20 December 2010, from www.alliancemagazine.org/node/3519

Leonard Downie, M. S. (2009). The reconstruction of American journalism. Retrieved on 20 December 2010, from www.cjr.org/reconstruction/the_reconstruction of american.php?page $=$ all

Lewis, C. (2007, p. 10). The growing importance of nonprofit journalism. Working Paper series, Retrieved on 20 December 2010, from http://irw.s3.amazonaws.com/ shorenstein2006.pdf

Lewis, C. (2009 para 4). 10 rules of the road for nonprofit centers. Retrieved on 20 December 2010, from http://irw.s3.amazonaws.com/ire journal2009.pdf.

Lewis, C. (2010). New journalism ecosystem thrives. Journalism ecosystem Retrieved on 29 October, 2010, from http://investigativereportingworkshop.org/ilab/story/ ecosystem

Manifesto, A. (n.d.). A manifesto. retrieved on 20 December 2010, from http://newsinitiative.org/taskforce/manifesto.html

Meyer, P. (2009). The vanishing newspaper : saving journalism in the information age. Columbia: University of Missouri Press.

Nichols, R. M. a. J. (2010). The death and life of American journalism. New York: Nation Books.

Nocera, J. (2008, para 5). Self-made philanthropists. Retrieved on 20 December 2010, from www.nytimes.com/2008/03/09/magazine/09Sandlers-t.html

ProPublica. (2011). 'Why we're publishing advertising, and where we stand on funding.' Retrieved on 20 December 2010, from www.propublica.org/article/whywere-publishing-advertising-and-where-we-stand-on-funding. 
ProPublica(a). (2011). Advertising acceptance policy. Retrieved on 20 December 2010, from www.propublica.org/about/propublica-advertising-acceptability-policy

Rosen, J. (1999 pg 72). What are journalists for? New Haven: Yale University Press.

Rotella, S. (2010, November 14). On the trail of Pakistani terror group's elusive mastermind behind the Mumbai siege. Retrieved on 20 December 2010, from www. washingtonpost.com/wp-dyn/content/article/2010/11/13/AR2010111304907.html

Rotella, S. (2010(a), November 13). The man behind Mumbai. Retrieved on 20 December 2010, from www.propublica.org/article/the-man-behind-mumbai

Schaffer, J. (2009). New media makers. Washington DC: J-Lab is a center of American University's School of Communication.

Schaffer, J. (2009, para 7, May 2009). New media makers. See case study: Voice of San Diego: www.kenn.org/toolkit/impact_studies/, from www.kenn.org/toolkit/ funding fit.

Schaffer, J. (2010, para 61). Entrepreneurship and the future of news. Retrieved on 20 December 2010, from www.j-lab.org/speeches/entrepreneurship_and_the_future of news/

Schultz, J. (1998, p. 19-22). Reviving the fourth estate : democracy, accountability and the media. Cambridge, Melbourne: Cambridge University Press

Serrin, W. L. B. a. W. (2005, p. 169). The watchdog role. The Press. K. H. Jamieson and G. Overholser. New York: Oxford University Press.

Walton, M. (2010). The nonprofit explosion. American Journalism Review.

Walton, M. (2010, para 7). Investigative shortfall. American Journalism Review.

Walton, M. (2010, para 87). Investigative Shortfall. American Journalism Review.

Bill Birnbauer, one of Australia's most senior journalists, became a senior lecturer in journalism at Monash University in December 2008. He has 34 years experience at The Age, The Sunday Age and The Herald. In 1996, Birnbauer led a team that won a Walkley award for best application of journalism to the print medium, for a narrative feature on the Port Arthur massacre. He has been a Walkley finalist four times. He is a member of the International Consortium of Investigative Journalists which is a project of the Centre for Public Integrity. He has been involved in two investigative projects with the consortium for which he was paid. He visited the United States in November 2010, with the support of a new appointees grant from Monash University. This article incorporates research conducted as part of a higher degree at Swinburne University. The author would like to thank Dr Tamara Kohn and Dr Len Webster for their advice and patience in answering a myriad of questions. bill.birnbauer@monash.edu 